\title{
Perancangan dan Implementasi Finite State Automata pada Pusheen Cat Maze Game dengan Adobe Flash
}

\author{
Affis Masturina Nisa*1, Hafidz Kurniansyah ${ }^{2}$ \\ ${ }^{1,2}$ Program Studi Manajemen Informatika, Fakultas Teknik, Universitas PGRI Madiun \\ e-mail:*11nisakmsh98@gmail.com, ${ }^{2}$ hafidzbmc86@gmail.com
}

\begin{abstract}
Abstrak - Sekarang ini banyak sekali media yang digunakan untuk pembelajaran, khususnya anak anak, dengan menggunakan media yang menarik, seperti game. Selain dapat menambah minat belajar, media game ini cukup efektif untuk : (1) mencapai tujuan pembelajaran, (2) merangsang kreativitas, (3) melatih konsentrasi. Penelitian yang dilakukan melalui 4 tahap menurut [1] yaitu identifikasi masalah, perancangan sistem game dan automata, implementasi sistem, pengujian sistem dan analisis hasil pengujian. Finite State Automata adalah mesin abstrak berupa sistem model matematika dengan masukan dan keluaran diskrit yang dapat mengenali bahasa paling sederhana (bahasa reguler) dan dapat diimplementasikan secara nyata. Automata digunakan dalam perancangan software dan hardware dalam perancangan sebuah game. Penelitian yang dihasilkan berupa aplikasi game maze (labirin) dengan Adobe Flash.
\end{abstract}

Kata kunci-Finite State Automata, Maze Game, Education Game, Adobe Flash

\section{Pendahuluan}

Seiring dengan berkembangnya jaman, teknologi kini makin diperbaharui untuk mempermudah pekerjaan manusia, dengan teknologi yang semakin maju dan berkembang maka kehidupan masyarakat pun ikut berubah. Mulai dari kehidupan ekonomi, politik, sosial dan budaya. Dari kemajuan inilah pula muncul juga masalah "ketergantungan" masyarakat terhadap kecanggihan teknologi. Salah satu teknologi yang mungkin cukup membuat pengaruh yang kuat yaitu game, game atau permainan merupakan salah satu industri elektronik digital yang kini berkembang pesat tidak terkecuali di Indonesia. Game sendiri menjadi idaman diberbagai kalangan masyarakat yang bertujuan untuk menghilangkan rasa jenuh dari rutinitas seharihari.

Adanya pandangan miring masyarakat terhadap game tidak semuanya benar, terlebih lagi para developer game masa kini lebih mementingkan aspek olah otak untuk mengembangkan kinerja otak, khususnya anakanak sehingga mereka akan lebih kreatif dan berkonsentrasi dalam menyelesaikan tantangan dalam sebuah game meskipun ada juga yang hanya mementingkan aspek hiburan saja.

Sebagai salah satu ilmu komputer, teori Bahasa dan Automata dijadikan dasar oleh model serta gagasan mendasar dalam membuat game ini. Dengan menggunakan metode ini, aplikasi "Maze Game" yang bergenre arcade ini kita dapat memberikan kecerdasan buatan agar dapat memiliki kecerdasan yang sama dengan pemain sehingga game menjadi lebih menantang.

Berdasarkan latar belakang pada masalah tersebut, dilakukan penelitian dengan judul "Perancangan dan Implementasi Finite State Automata pada Pusheen Cat Maze Game dengan Adobe Flash", yang lebih bersifat pada edukasi dalam permainan ini. Didapatkan tinjauan literatur sebagai berikut:

\begin{tabular}{|l|l|c|l|c|}
\hline \multirow{3}{*}{ No } & \multirow{2}{*}{ Judul } & Terbitan, & \multicolumn{2}{|c|}{ Perbedaan Penelitian } \\
\cline { 4 - 5 } & & Tahun & Literatur & Penulis \\
\hline \multirow{6}{*}{1} & Perancan & Y. & Studi Kasus & Studi Kasus \\
& gan dan & Yohanes, & yang & yang \\
& Impleme & http://reposi & dirancang & dirancang \\
& ntasi & tory.uksw.e & adalah & adalah \\
& Finite & du/bitstrea & Game Quiz & Pusheen \\
& State & m/1234567 & Ular & Cat Maze \\
& Automata & $89 / 6366 / 2 /$ & Tangga & Game \\
& Pada & T1_672007 & Berbasis & dengan \\
& Game & 111 Full\% & Android & Adobe \\
& Quiz Ular & 20 text.pdf, & & Flash \\
& Tangga & 2013 & & \\
& Berbasis & & & \\
& Android & & & \\
\hline
\end{tabular}

\section{LANDASAN TEORI}

Permainan (game) adalah salah satu implementasi pada ilmu komputer. Perkembangan yang pesat ini dikarenakn mayoritas pengguna komputer yang 
menghabiskan sebagian besar waktu mereka di depan komputer dalam program permainan. Salah satu permainan yang diminati adalah permainan Labirin. Permainan Labirin adalah permainan mencari jalan keluar yang bertujuan menentukan jalur yang tepat untuk mencapai tujuan yang telah ditetapkan. Selama proses penentuan jalur tersebut, jika menemui jalan buntu maka akan dilakukan backtrack sampai kembali menemukan jalur yang tepat untuk mencapai tujuan.

Finite State Automata atau biasa disebuat FSA, merupakan sebuah model matematika dari suatu sistem yang menerima suatu input dan menghasilkan sebuah output diskrit. FSA memiliki state yang banyaknya terbatas, dan dapat dipindahkan dari satu state ke state lain[2]. State adalah kondisi, keadaan, atau kedudukan. Prinsip kerja Finite State Automata sendiri adalah dengan cara mesin pembaca perintah membaca memori masukan yang berupa tape yaitu 1 karakter disetiap menggunakan head baca yang dikendalikan oleh kontak kendali state berhingga dimana pada mesin tersebut terdapat sejumlah state berhingga. Finite State Automata selalu dalam kondisi yang disebut dengan state awal pada saat finite automata mulai membaca tape[3]. Perubahan dari state terjadi pada mesin saat sebuah karakter selanjutnya dibaca. Ketika sebuah head telah sampai pada akhir-an tape dan dalam kondisi state akhir, maka string yang terdapat pada tape akan dikatakan diterima Finite Automata.

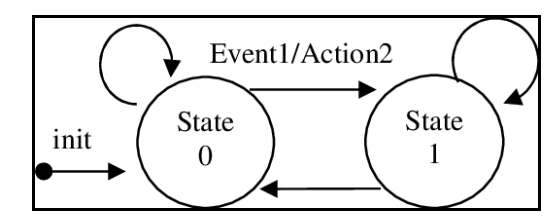

Gambar 1. Diagram State Sederhana

(Sumber: Setiawan, 2006)

Gambar 1 memperlihatkan FSA dengan dua buah state dan dua buah input serta empat buah output yang berbeda seperti terlihat pada gambar, ketika sistem mulai dihidupkan, sistem akan bertransisi menuju State0, pada keadaan ini sistem akan menghasilkan Actionl jika terjadi masukan Evento, sedangkan jika terjadi Event1 maka Action2 akan dieksekusi kemudian sistem selanjutnya bertransisi ke keadaan Statel dan seterusnya[4]. Game berasal dari Bahasa Inggris yang jika diartikan menjadi permainan. Samuel Henry mengatakan bahwa Game merupakan bagian tak terpisahkan dari keseharian anak, sedangkan sebagian orang tua menuding game sebagai penyebab nilai anak turun, anak tak mampu bersosialisasi, dan tindakan kekerasan yang dilakukan anak"[5]. Setiap game memiliki peraturan main yang berbeda dari beberapa game lain sehingga ragam game semakin banyak dan beragam. Fungsi dari game sendiri sebagai penghilang stress dan rasa jenuh akan aktifitas sehari-hari.

Tujuan dalam Game adalah sebagai mendidik, menghibur para pemain game. Dalam sebuah buku berjudul "the art of computer game design", sebuah rancangan game merupakan suatu aktivitas komplek yang dapat diturunkan ke prosedur formal. Ada beberapa langkah dalam merancang game yaitu: (1) Memilih tujuan dan topik, (2) Penelitian dan persiapan, (3) Tahap design, (4) Tahap pra-pemrograman, (5) Tahap pemrograman, (6) Tahap playtesting, dan (7) Post-mortem [6]. Permainan Maze (Labirin) adalah sebuah permainan mencari jalan keluar yang tujuannya untuk menentukan jalur yang tepat untuk mencapai tujuan yang telah ditetapkan. Selama proses penentuan jalur tersebut, jika menemui jalan buntu maka akan dilakukan proses backtrack sampai kembali menemukan jalur tepat untuk mencapai tujuan[7].

Adobe Flash atau sebelumnya Macromedia Flash merupakan software multifungsi. Software ini mempermudah dalam pembuatan animasi web, selain itu action script pada Adobe Flash juga dapat dimanfaatkan menjadi game yang mudah dan efektif. Adobe Flash menyuguhkan 5 versi action script yang disesuaikn kebutuhan pengguna. Versi - versi action script pada Adobe Flash yaitu (1) Action Script 1.0 merupakan versi sederhana dan digunakan pada kebanyakan versi Flash Lite Player, (2) Action Script 2.0 secara praktis lebih mudah dipelajari dan dipahami. Kinerjanya sedikit lebih cepat dari versi sebelumnya sehingga sesuai digunakan untuk proyek yang tidak membutuhkan komputasi yang kompleks, (3) Action Script 3.0 versi ini menggunakan konsep pemrograman berorientasi objek sehingga dapat mengeksekusi perintah secara cepat, (4) Flash Lite 1.x, 2.x, dan 3.x. Merupakan versi Action Script yang khusus dirancang untuk menjalankan aplikasi Flash Lite 1.x pada perangkat seluler [8].

\section{METODE}

Ada 4 tahapan dalam merancang Finite State Automata pada sebuah game. Tahapannya antara lain : (1) Identifikasi Masalah, (2) Perancangan Sistem, (3) 
Implementasi Sistem, dan (4) Pengujian Sistem dan Analisis Hasil Pengujian.

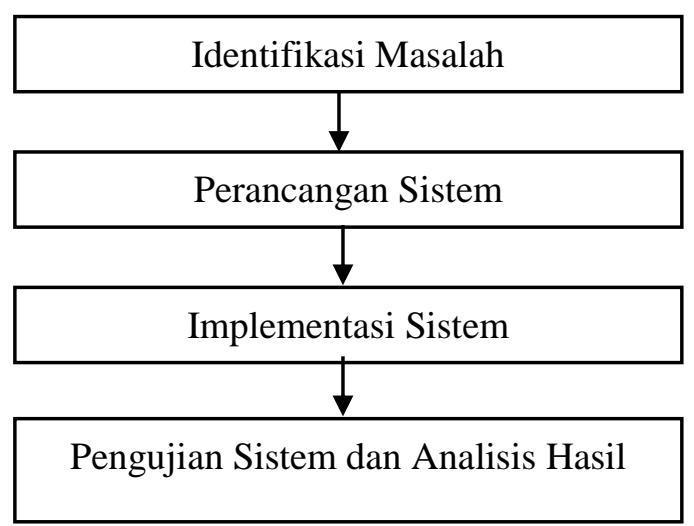

Gambar 2. Tahapan Penelitian

Pada gambar 2 tahapan penelitian, dapat dijelaskan sebagai berikut. Tahapan 1 : Identifikasi Masalah yaitu mengumpulkan beberapa data mengenai pembuatan game pada Adobe Flash. Tahapan 2 : Perancangan Sistem yaitu meliputi proses perancangan game dan elemen game. Tahapan 3 : Implementasi Sistem yaitu game yang sudah dirancang di uji. Tahapan 4 : Pengujian Sistem dan Analisis Hasil Pengujian yaitu pengujian ulang dan menganalisis hasil pengujian itu dihubungkan dengan sistem Automata[9]. Use Case Diagram berfungsi untuk menggambarkan kebutuhan sistem dari sudut pandang user, memfokuskan pada proses komputerisasi, menggambarkan hubungan antara use case dan actor use case, menggambarkan proses sistem [10].

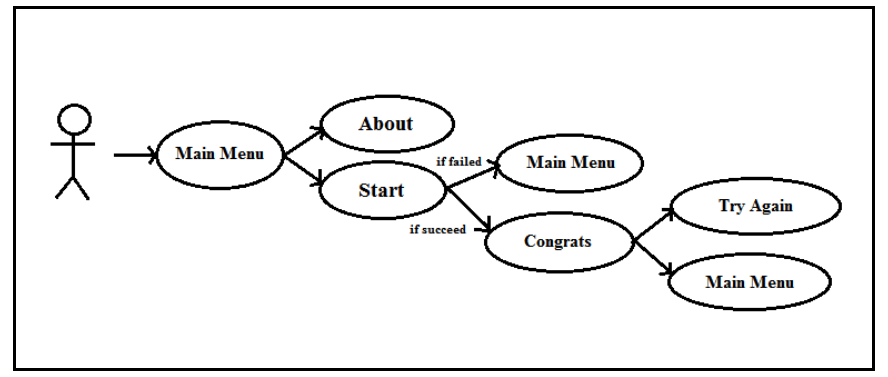

Gambar 3. Use Case Diagram

Gambar 3 menunjukkan Use Case Diagram. Player berada pada Main Menu, dimana ada opsi About dan Start. About adalah profil dari peneliti, sedangkan Start untuk memulai game. Selanjutnya, jika gagal maka otomatis akan mengarah ke Main Menu, sedangkan jika sukses, akan tampil ucapan Congrats. Pada Congrats disini, ada opsi Try Again dan Main Menu. Try Again adalah mengulang lagi permainan sedangkan Main Menu akan menuju kembali ke menu awal. Activity Diagram menggambarkan aliran aktivitas dalam sistem yang sedang dirancang, bagaimana masing - masing aliran dimulai, apa keputusan yang terjadi dan bagaimana aktivitas tersebut berakhir. Gambar 4 menunjukkan activity diagram saat aplikasi itu dijalankan. Player yang menjalankan aplikasi, aplikasi menampilkan menu, lalu player dapat memilih langsung Start untuk bermain atau melihat profil peneliti melalui About. Jika game yang dimainkan gagal, maka akan kembali ke main menu, sedangkan jika game yang dimainkan sukses maka akan berlanjut ke tampilan Congratsi dimana di tampilan tersebut ada tombol Try Again itu mencoba game itu kembali, dan juga ada tombol Main Menu untuk kembali ke menu utama. 


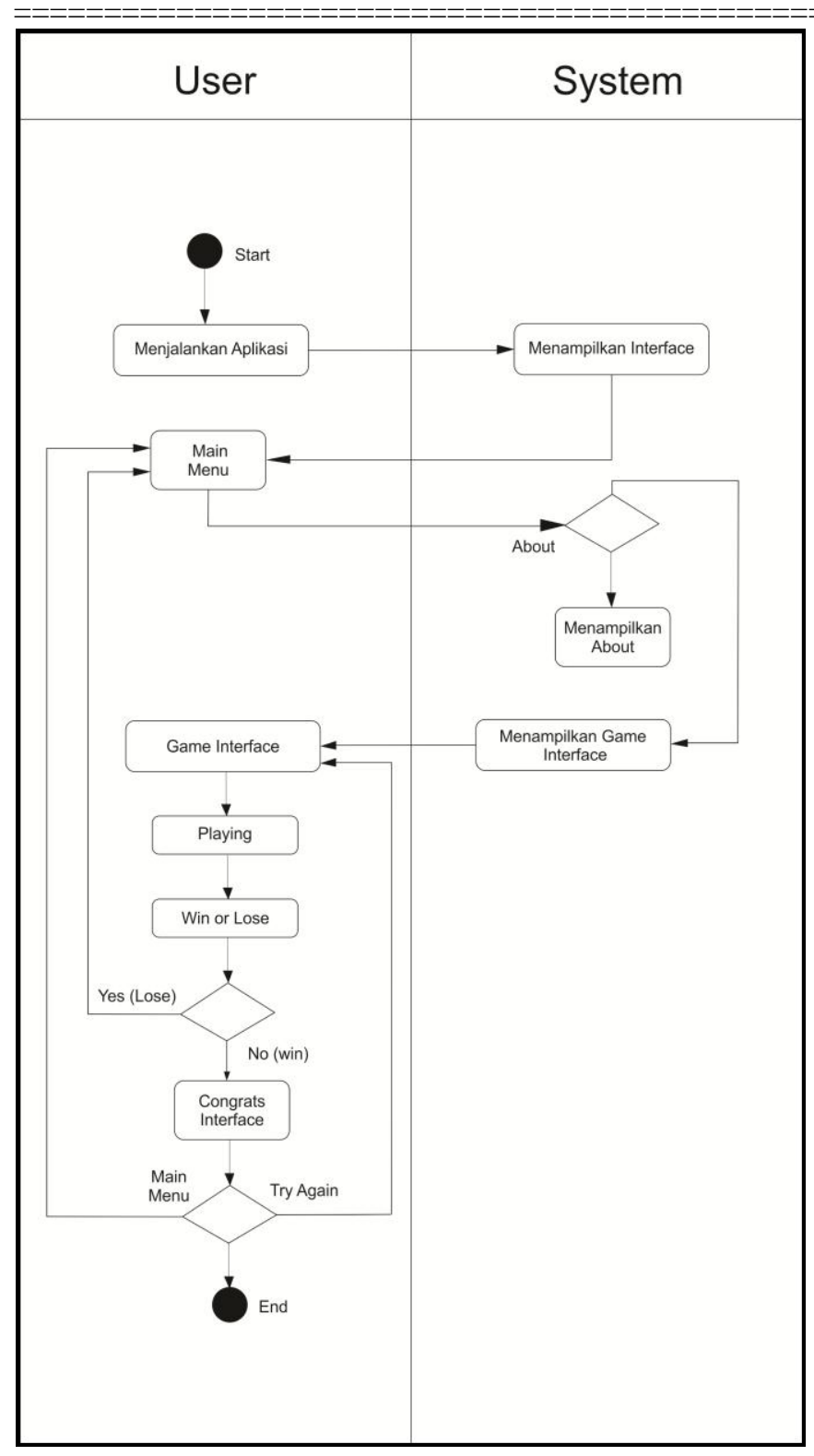

Gambar 4. Activity Diagram

Rancangan antarmuka Game Pusheen Cat Maze ditunjukkan pada Gambar 5.

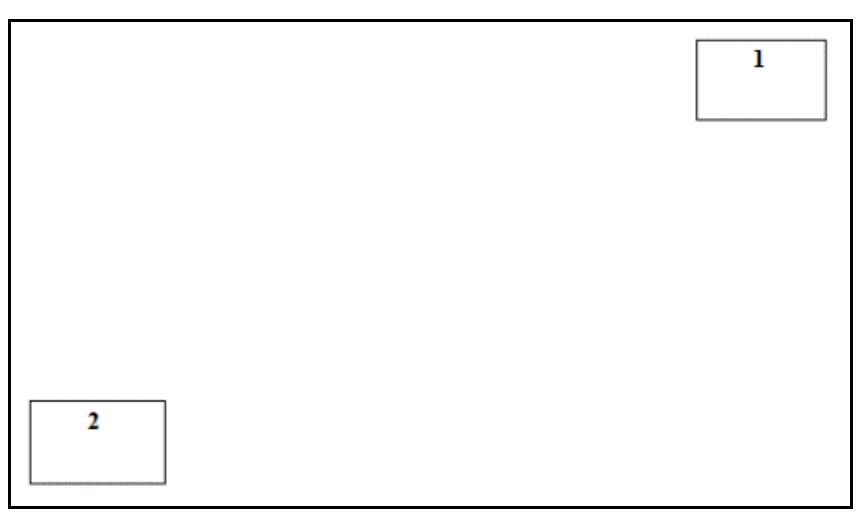

Gambar 5. Main Menu
Pada Gambar 5 menunjukkan Main Menu atau Menu Awal pada game saat dijalankan. Ada 2 tombol pada Main Menu, yaitu (1) About yang berisi identitas peneliti, (2) Start untuk memulai permainan. Ketika player memilih Start, player akan masuk ke permainan pada Gambar 6.

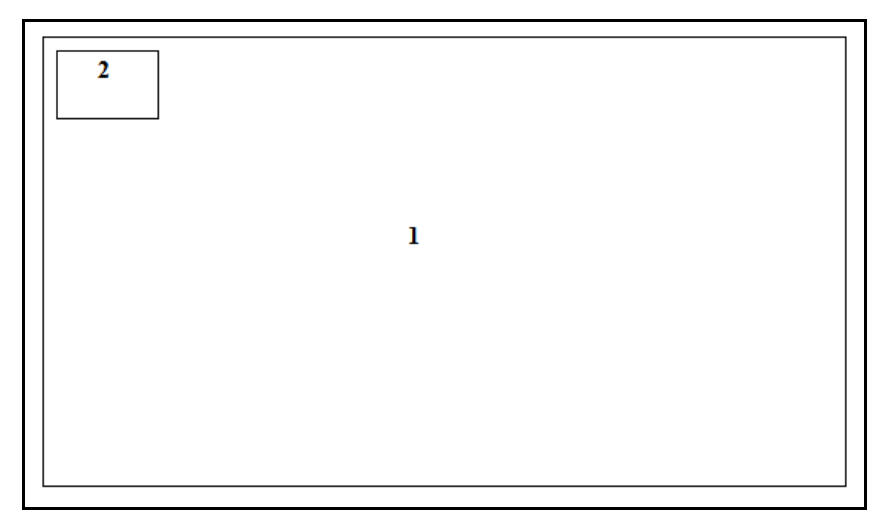

Gambar 6. Game Interface

Pada Gambar 6 menunjukkan Game Interface. Dijelaskan sebagai berikut: (1) Interface untuk Labirin, (2) Titik Hitam (Finish). Jika mengenai luar garis labirin, otomatis akan kembali ke Main Menu, sedangkan jika sukses, akan mengarah pada tampilan Congrats seperti pada Gambar 7.
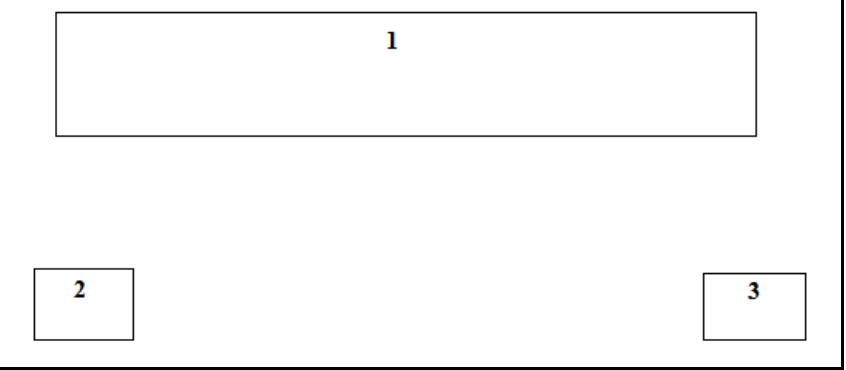

Gambar 7. Tampilan Congrats

Pada Gambar 7 menunjukkan Tampilan Congrats. Dijelaskan sebagai berikut: (1) Tulisan Congrats, (2) Try Again, (3) Main Menu. 


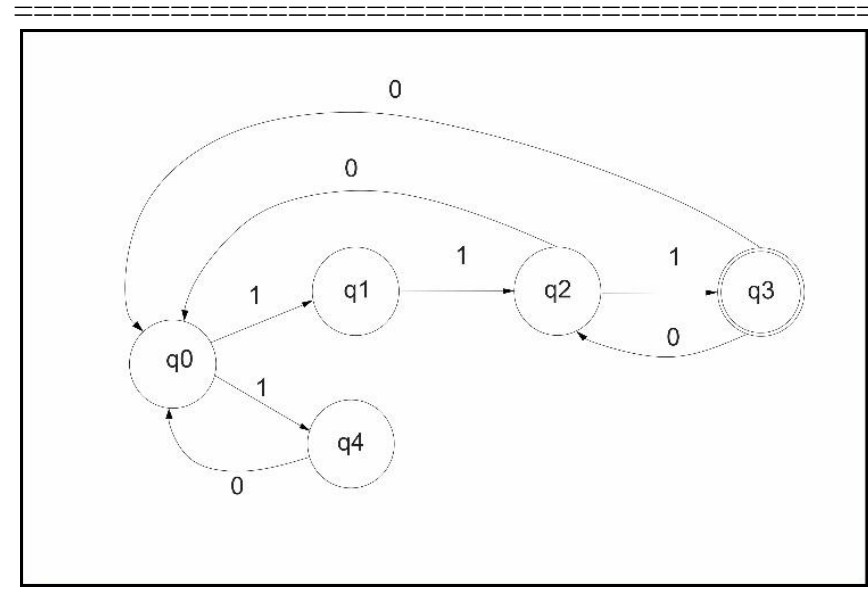

Gambar 8. Rancangan FSA Pusheen Cat Maze Game

Pada Gambar 8 menunjukkan Rancangan FSA, Konfigurasi DFA tersebut sebagai berikut:

$\mathrm{Q}=\{\mathrm{Q} 0, \mathrm{Q} 1, \mathrm{Q} 2, \mathrm{Q} 3, \mathrm{Q} 4\}$

$\sum=\{1,0\}$

$\mathrm{S}=\mathrm{Q} 1$

$\mathrm{F}=\mathrm{Q} 3$

$\delta$ (fungsi transisi)

Tabel 1. Tabel Konfigurasi $D F A$

\begin{tabular}{|c|c|c|}
\hline$\delta$ & 0 & 1 \\
\hline Q0 & - & Q1 \\
\hline Q1 & - & Q2 \\
\hline Q2 & Q0 & Q3 \\
\hline Q3 & Q0, Q2 & - \\
\hline Q4 & Q0 & Q0 \\
\hline
\end{tabular}

Ada 5 state yaitu Main Menu (Q0), Start (Q1), Gameplay (Q2), Congrats (Q3), About (Q4). Sedangkan inputnya adalah 1 dan 0 .

\section{HASIL}

Game Pusheen Cat Maze merupakan Game berbasis Flash untuk pemain tunggal. Di dalam game ini, player bermain dengan cara mengarahkan kursor menuju lokasi akhir melalui labirin. Jika kursor terkena luar jalur labirin, otomatis gagal. Berikut adalah rancangan Game Pusheen Cat Maze.
Print ISSN: 2615-7233

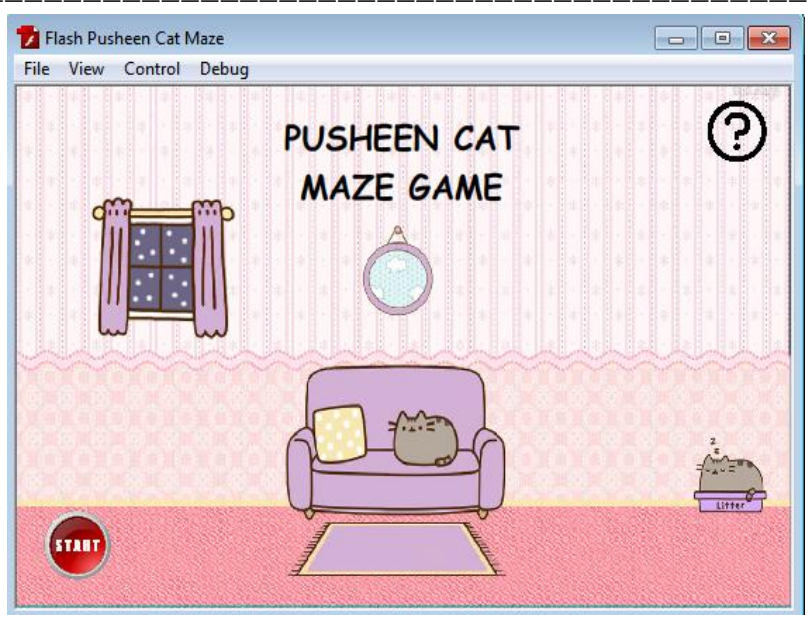

Gambar 9. Menu Utama Game

Gambar 5 menunjukkan tampilan awal yaitu Menu Utama. Ada 2 tombol pilihan, yaitu (1) About dan (2) Start. Ketika player memilih Start maka akan langsung ke permainan pada Gambar 6.

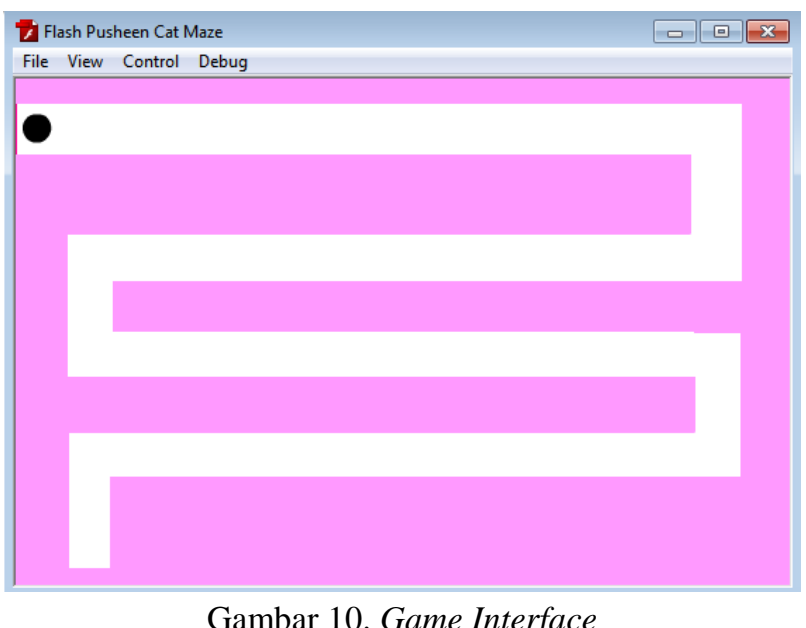

Gambar 6 menunjukkan game interface, dimana terdapat labirin dan titik hitam. Kursor harus menuju ke lokasi akhir (titik hitam) agar sukses. Jika gagal maka akan kembali ke Menu Utama (Main Menu). Jika sukses, akan menuju ke tampilan Congrats seperti pada Gambar 7. 


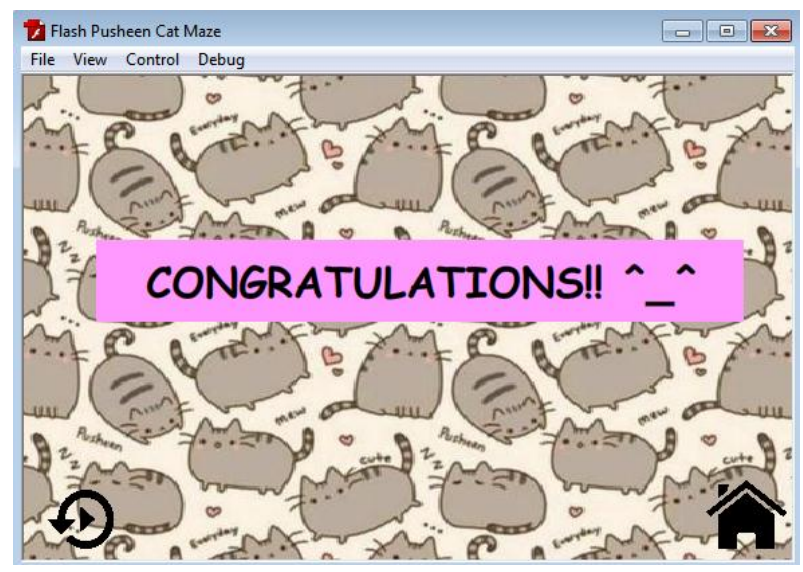

Gambar 11. Congrats Interface

Pada Gambar 7 menunjukkan Congrats Interface, dimana terdapat tampilan tulisan Congrats karena sukses dalam permainan. Dan juga 2 tombol pilihan, (1) Try Again untuk mencoba permainan itu kembali, dan (2) Main Menu untuk menuju kembali ke Menu Utama. Hasil pengujian dari implementasi Finite State Automata dijelaskan sebagai berikut.

Tabel 2 Tabel Hasil Pengujian Implementasi FSA

\begin{tabular}{|l|l|c|}
\hline No & \multicolumn{1}{|c|}{ Status } & Hasil Pengujian \\
\hline 1. & Main Menu & Berjalan dengan baik \\
\hline 2. & Start & Berjalan dengan baik \\
\hline 3. & Gameplay & Berjalan dengan baik \\
\hline 4. & Congrats & Berjalan dengn baik \\
\hline
\end{tabular}

\section{KESIMPULAN}

Berdasarkan hasil penelitian, dan pembahasan yang dilakukan dapat ditarik kesimpulan sebagai berikut: (1) FSA dapat membantu pengembangan Game yang dijalankan, (2) Game Pusheen Cat Maze membantu pemain khususnya anak - anak untuk melatih konsentrasinya. Saran pengembangan yang dapat diberikan untuk penelitian lebih lanjut adalah: (1) Grafik game ditingkatkan menjadi 3D, (2) Mengembangkan sistem pada game seperti reward, level dsb.

\section{DAFTAR PUSTAKA}

[1] Y. Yohannes, "Perancangan dan Implementasi Finite State Automata pada Game Quiz Ular Tangga Berbasis Android," 2013.

[2] A. Farmanbar, S. Firouzi, S.-J. Park, K. Nakai, K. Uchimaru, dan T. Watanabe, "Multidisciplinary insight into clonal expansion of HTLV-1-infected cells in adult T-cell leukemia via modeling by deterministic finite automata coupled with highthroughput sequencing," 2017.

[3] D. Nagamouttou, I. Egambaram, M. Krishnan, dan P. Narasingam, "A verification strategy for web services composition using enhanced stacked automata model," 2015.

[4] D. Liu, Z. Huang, Y. Zhang, X. Guo, dan S. Su, "Efficient Deterministic Finite Automata Minimization Based on Backward Depth Information," PLoS One, vol. 11, no. 11, hal. e0165864, Nov 2016.

[5] M. Mustofa, S. Sidiq, dan E. Rahmawati, "PENERAPAN FINITE STATE MACHINE UNTUK PENGENDALIAN ANIMASI PADA VIDEO GAME RPG NUSANTARA LEGACY," $J$. Sist. Komput. Musirawas, vol. 3, no. 1, hal. 1, Jun 2018.

[6] C. Crawford, Chris Crawford on game design. New Riders, 2003.

[7] N. Purwandari, “APLIKASI PERMAINAN LABIRIN 3D MENGENAL OBJEK WISATA DI INDONESIA MENGGUNAKAN MOBILE."

[8] G. Agung, Kupas Tuntas Flash CS5. Jakarta: PT. Elex Media Kompotindo, 2009.

[9] M. Jamilah dan W. Nurmansyah, "Rancangan Dan Implementasi Aplikasi Alat Bantu Pembelajaran Visualisasi Finite State Automata (Versi Pembuktian Graph ke Tupel)," Agu 2018.

[10] D. S. Hormansyah, A. R. T. H. Ririd, dan D. T. Pribadi, "IMPLEMENTASI FSM (FINITE STATE MACHINE) PADA GAME PERJUANGAN PANGERAN DIPONEGORO," J. Inform. Polinema, vol. 4, no. 4, hal. 290, Agu 2018. 